\title{
Analysis of the competitiveness of pipeline maintenance service providers in oil wells in the state of Tabasco
}

\section{Análisis de la competitividad de las empresas proveedoras de servicios de mantenimiento de tuberías en pozos petrolíferos en el estado de Tabasco}

\author{
GARCÍA-CANCINO, Ismael Adrián† t, LOPEZ-VALDIVIESO, Leticia*, ELISEO-DANTÉS, \\ Hortensia and MOREJÓN-SÁNCHEZ, Juana María
}

Tecnológico Nacional de México/Instituto Tecnológico de Villahermosa, Mexico

ID $1^{\text {st }}$ Author: Ismael Adrián, García-Cancino / ORC ID: 0000-0002-5330-0432, Researcher ID Thomson: RID-17585, CVU CONACYT ID: 1003688 ID $1^{\text {st }}$ Co-author: Leticia, López-Valdivieso / ORC ID: 0000-0001-6288-3636, Researcher ID Thomson: G-5753-2018,
CVU CONACYT ID: 67839

ID $2^{\text {nd }}$ Co-author: Hortensia, Eliseo-Dantés / ORC ID: 0000-0003-4006-4669, Researcher ID Thomson: F-6749-2018, CVU CONACYT ID: 411079

ID $3^{\text {rd }}$ Co-author: Juana María, Morejón-Sánchez / ORC ID: 0000-0002-9930-181X, Researcher ID Thomson: ABE2879-2020, CVU CONACYT ID: 362413

\begin{abstract}
In the industrial sector, it is important that companies have a high profitability, with strategies for the provision of services or product development that meet or exceed the demands of the market, this is called competitiveness. Maintaining a holistic approach within organizations requires the analysis and measurement of context variables, as well as the implementation of a culture of quality and continuous improvement. In the oil industry, well pipeline maintenance services are activities of the utmost importance to keep the energy sector productive, therefore it is important that companies engaged in this area be competitive. This study analyzes the impact of context variables on the competitiveness of companies that provide maintenance services to oil well pipelines, seeking that in a comprehensive manner and on the basis of the results obtained, determine the relationship they have with respect to their competitiveness, to propose improvement strategies that lead companies to evolve towards states of improvement with levels of competitiveness that allow them to position themselves at world-class levels.
\end{abstract}

Competitiveness, Strategies, Maintenance

\begin{abstract}
Resumen
En el sector industrial, es importante que las empresas tengan gran rentabilidad, con estrategias de prestación de servicios o desarrollo de productos que cumplan o superen las exigencias del mercado, a esto se le llama competitividad. Mantener un enfoque integral dentro de las organizaciones requiere del análisis y medición de las variables del contexto, así como la implementación de una cultura de calidad y mejora continua. En la industria petrolera, los servicios de mantenimiento a tuberías de pozos son actividades de suma importancia para mantener productivo al sector energético, por tanto, es relevante que las empresas dedicadas a este rubro sean competitivas. En el presente estudio se analiza la incidencia de las variables del contexto en la competitividad de las empresas que proveen servicios de mantenimiento a las tuberías de los pozos petroleros, se busca que de manera integral y a partir de los resultados obtenidos, se determine cuál es la relación que guardan respecto a su competitividad, para proponer estrategias de mejora que conduzcan a las empresas a evolucionar hacia estados de mejora con niveles de competitividad que les permita posicionarse en niveles de clase mundial.
\end{abstract}

Competitividad, Estrategias, Mantenimiento

Citation: GARCÍA-CANCINO, Ismael Adrián, LOPEZ-VALDIVIESO, Leticia, ELISEO-DANTÉS, Hortensia and MOREJÓN-SÁNCHEZ, Juana María. Analysis of the competitiveness of pipeline maintenance service providers in oil wells in the state of Tabasco. Journal of Engineering Applications. 2021. 8-26:1-6.

\footnotetext{
* Correspondence of the Author (Email: leticia.lv@villahermosa.tecnm.mx)

$\dagger$ Researcher contributing as first author.
} 


\section{Introduction}

The competitiveness of companies is an indicator of great importance that allows knowing the competitive advantage that a company has through its methods of production and organization in relation to those of its rivals in a specific market (Barquero, 2003). Porter (1990) and Krugman (1994) have pointed out that the competing companies are not the nations; a country is made competitive by the competitive companies there. These are therefore the foundations of competitiveness.

Within the oil industry in Mexico, and specifically in the state of Tabasco, competitiveness becomes present in different areas, for the obtaining of crude oil, Petróleos Mexicanos (PEMEX), which is the State Productive Company, it requires a range of services to keep the sector productive, be it exploration, drilling, extraction, and even maintenance of the oil well infrastructure. And that is why there are several companies dedicated to each of these items, which are generally subcontracted to perform these specific services, and certainly compete to position themselves within the market.

As regards maintenance to well infrastructure, it is emphasized that this type of maintenance is provided to the pipes used in the extraction processes, since these operations due to their constant use and operation, tend to deteriorate the pipes. and as a result of such use, liquid handling and exposure to the medium tend to corrode, and it is here that the correct state of these pipelines has a great impact on quality assurance in the processes for obtaining crude oil, and as such, on keeping the oil sector healthy, it represents an economic sustenance for the tabasco state and the nation at large.
However, in all this oil sector, according to Cervilla (2001) there is the problem that the less renowned companies focused on providing services and operating in a subcontracted manner share a set of characteristics, considered as main weaknesses concerning the market in which they are managed, these are: high costs for carrying out the service, zero diversification in the work, technological gap (infrastructure, machinery and instrumentation), concentration in few markets, and to that it is possible to add a poor culture of quality among the participants within the organization, possibly due to the context in which each country or region is immiscuded. With all this, it can be inferred that some of the variables in the context may be significantly affecting the competitiveness of the oil sector, and particularly those dedicated to providing maintenance services to pipelines in oil wells, they are likely not to be taking into account a comprehensive and systemic approach to the development of their activities.

It should be noted that, in the oil industry in particular, the transformations of the economy are not only about internal reforms, but also about the changing institutional context that is being built at the international level, particularly through the various multilateral treaties, they serve as a framework for national transformations by providing rules for investment and trade, and of course, in the specific case of the energy sector, for the processes of deregulation, liberalization and creation of competitive energy markets, as Walde (2002) states.

That is why, in any country, it is understood that the development and delivery of services cannot continue to be considered only in a local scenario, since external competition is dealt with on the market with international quality and costs, By grabbing this segment identifying itself as world-class companies, able to compete in any market with the best of the sector, leaving behind the least prepared ones since their response to change and evolution as leading entities are limited. 
Through a study that considers the variables of the context with the application of a self-diagnostic instrument it is possible to know the level of competitiveness that the companies that provide services for the maintenance of pipes in oil wells, the information gathered through experts using the measuring instrument will allow an analysis of the actual situation with its factors of incidence among the variables of greater or lesser dependence within the est scheme

\section{Oil activity in the state of Tabasco}

The state of Tabasco is a very active region in the oil sector, belongs to the Southern Region and contributes a high percentage of the country's energy wealth (more than $35 \%$ in conjunction with Campeche). It is estimated that this federal entity generates 224 barrels of crude oil a day.

At present, along the limits of the Tabasqueño state, wells dedicated to the extraction of oil can be found, so in this region several companies are established, which work as contractors to carry out different services, emphasizing the maintenance of pipes. For this reason, Petróleos Mexicanos (PEMEX), carries out continuous searches of the maintenance services for the pipes of the wells, and these are provided as subcontracting, as mentioned, by companies that are dedicated specifically to this item. Thus, the main situation in the sector is that these companies must comply fully with the requirements of the service, an issue that is closely related to various organizational elements, they involve productivity and quality, which can be achieved by working from a very early stage with a comprehensive approach, adding that these organizations must understand that the environment is very volatile. it is therefore essential to develop strategies to have the capacity to respond to the evolution of the context in order to remain productive and of quality, and therefore competitive.
In the case of these large companies dedicated to the provision of services, recently in Tabasco the Tabasco Institute of Oil and Sustainable Development (ITP and DS) was created, which aims to strengthen existing companies and also to create new tobacco companies of high technological value, as well as preparing and strengthening the competencies and skills of professionals and technicians in today's workforce. This institution created a council of technical oil advisers, in which experts with 40 years of experience in the world of work participate, carrying out different research and analysis of the different existing companies, The concern was to analyze the situation of the companies in the state of Tabasco to find out if they were able to offer quality services to the new projects in the sector. This Institute, when carrying out various analyzes in the tobacco sector, the first thing that detected was the lack of certification, therefore it is essential to orient them to be productive and competitive, by creating quality models based on a holistic approach that provide different strategies to provide them with a greater opportunity for growth.

Analysis of the competitiveness of the pipeline maintenance sector in the state of Tabasco, using a data collection instrument

In order to understand the current state of competitiveness in the specific aspect of pipeline maintenance to wells within the oil sector, a measuring instrument was generated, which intrinsically involved the six variables of the context, generally called self-test questionnaire, which was applied to experts from four companies, who, with their experience and hierarchy within the organizations, they obtained valuable and reliable information on the current state of the factors involved in the study related to each of the companies in which they work.

\section{Methodology for the application of the measuring instrument}

The measuring instrument consisted of a questionnaire that was divided into several aspects which represent and/or involve the variables of the context, and in each of the items are mentioned factors or elements that to the extent that each organization fulfills each of them, it can be inferred that the company is at the specific productivity level and therefore it will be possible to know its level of competitiveness. 
The aspects analyzed in this study are presented in Table 1 and within each aspect the element corresponding to the current situation of the company can be selected in each question, the frequencies of the responses provided were concentrated in Table 1.

A total of sixteen instruments were applied, which yielded results in which it was possible to perform independent analyzes of each aspect, representing the context variables considered.

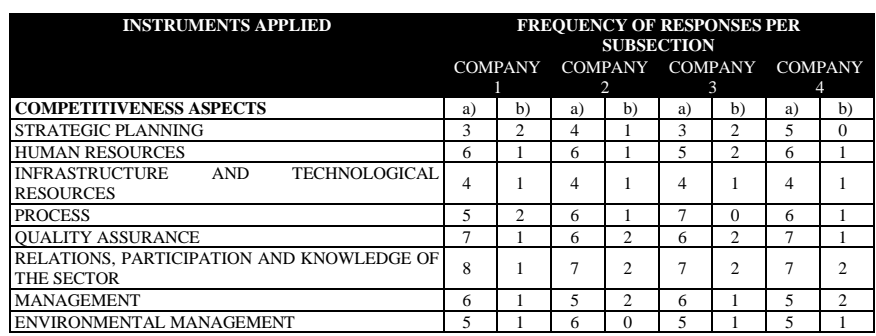

Table 1 Aspects of competitiveness analyzed in the measurement instrument to evaluate the comprehensive diagnosis

Source: Author's contribution (June 2021)

\section{Analysis of results}

Each item was determined a weighting value depending on the total number of questions in each aspect, which represent the compliance value of each company.

The weighting values for the questions for each aspect analyzed were:

- $\quad$ Strategic planning: 0.20 per question.

- Human resources: 0.14 per question.

Infrastructure and technological resources: 0.20 per question.

Processes: 0.14 per question.

Quality assurance: 0.12 by question.

Industry relationships, participation and knowledge: 0.11 by question.

Administration: 0.14 by question.

Environmental management: 0.16 by question
After the weights in each aspect it was determined that if "a)" were answered, these values were added together, and if "b)" was answered, the weighted value for the question in question was lost, so each independent aspect can add a maximum of 1 in its compliance value. And the sum of the values was made on the basis of the answers of the experts in the questionnaire applied.

This sum of values is reflected in Table 2, where it was possible to measure the level of compliance of each company selected for the sample, thus being able to observe more easily the current competitiveness status of the sector, and to obtain an average value in each aspect. Thus, with the obtaining of Table 1, the frequency of each aspect analyzed was multiplied, by each weighting value, to obtain an average value of the sector that represents the level of compliance in each aspect in general, it was also possible to convert to a percentage so that the level of compliance in each aspect of competitiveness that was analyzed in this study could be more clearly known.

\begin{tabular}{|c|c|c|c|c|c|c|}
\hline \multicolumn{7}{|c|}{ MEASURING BUSINESS COMPETITIVENESS } \\
\hline \multirow[t]{3}{*}{$\begin{array}{c}\text { COMPETITIVENES } \\
\text { S ASPECTS }\end{array}$} & \multirow{2}{*}{\multicolumn{4}{|c|}{$\begin{array}{c}\text { COMPLIANCE VALUE } \\
\text { BY ITEM } \\
\text { VALUES OBTAINED } \\
\text { FROM THE SAMPLE }\end{array}$}} & \multirow{3}{*}{$\begin{array}{l}\text { AVERAGE } \\
\text { VALUE OF } \\
\text { THE } \\
\text { SECTOR }\end{array}$} & \multirow{3}{*}{$\begin{array}{l}\text { LEVEL IN } \\
\% \text { OF } \\
\text { THE } \\
\text { SECTOR }\end{array}$} \\
\hline & & & & & & \\
\hline & 1 & 2 & 3 & 4 & & \\
\hline $\begin{array}{l}\text { STRATEGIC } \\
\text { PLANNING }\end{array}$ & 0.60 & 0.80 & 0.60 & 1 & 0.75 & $75 \%$ \\
\hline $\begin{array}{l}\text { HUMAN } \\
\text { RESOURCES }\end{array}$ & 0.84 & 0.84 & 0.70 & .84 & 0.80 & $80 \%$ \\
\hline $\begin{array}{l}\text { INFRASTRUCTURE } \\
\text { AND } \\
\text { TECHNOLOGICAL } \\
\text { RESOURCES }\end{array}$ & 0.80 & 0.80 & 0.80 & 0.80 & 0.80 & $80 \%$ \\
\hline PROCESS & 0.70 & 0.84 & 1.0 & 0.84 & 0.84 & $84 \%$ \\
\hline $\begin{array}{l}\text { QUALITY } \\
\text { ASSURANCE }\end{array}$ & 0.84 & 0.72 & 0.72 & 0.84 & 0.78 & 78\% \\
\hline $\begin{array}{l}\text { RELATIONS, } \\
\text { PARTICIPATION } \\
\text { AND KNOWLEDGE } \\
\text { OF THE SECTOR }\end{array}$ & 0.88 & 0.77 & 0.77 & 0.77 & 0.79 & $79 \%$ \\
\hline MANAGEMENT & 0.84 & 0.70 & 0.84 & 0.70 & 0.80 & $80 \%$ \\
\hline $\begin{array}{l}\text { ENVIRONMENTAL } \\
\text { MANAGEMENT }\end{array}$ & 0.80 & 1.0 & 0.80 & 0.80 & 0.85 & $85 \%$ \\
\hline
\end{tabular}

Table 2 Aspects of competitiveness analyzed in the measurement instrument to evaluate the comprehensive diagnosis

Source: Author's contribution (June 2021)

After obtaining Table 2, the levels of competitiveness of the sector in each of the aspects studied were known through the percentage calculation. This generated Chart 1, which represents these levels in detail. 


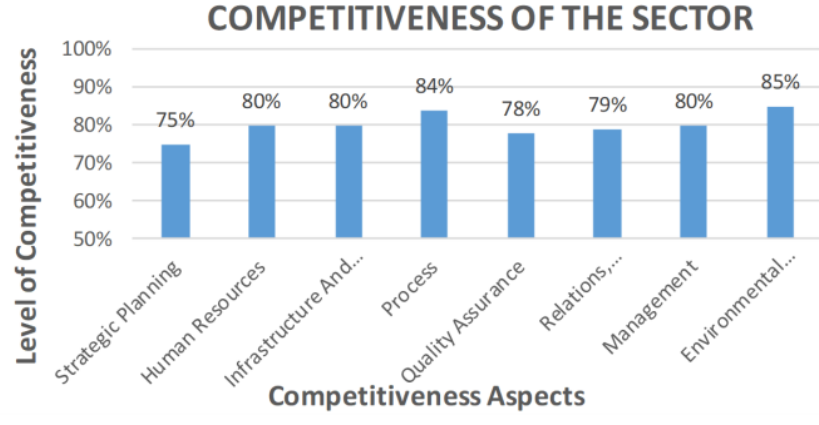

Figure 1 Performance of the competitiveness of the sector Source: Author's contribution (June 2021).

Figure 1 shows that the percentages of competitiveness achieved in each of the items within the sector of companies providing maintenance services to oil well pipelines fluctuate between $75 \%$ and $85 \%$, where obviously. By performing a global analysis, it can be seen that in the graph there are almost three frequencies in reference to the levels of competitiveness in each aspect, within which it is possible to analyze them group and individually.

The first level of frequency, on a bottomup scale, are the aspects that do not reach a minimum level of $80 \%$, these are three, the Strategic Planning, Quality Assurance and the Relations, Participation and Knowledge of the Sector, it can therefore be assumed that within this sector, we are not working in the best way on these aspects, since they are the ones that achieved the lowest level of compliance with the elements that favor competitiveness, and then it is vital to reinforce these points in a systematic way, focusing on creating strategies that counteract these inadequacies or weaknesses within each of the organizations involved in the sector.

At the second level of frequency, there are the items that achieve an exact level of $80 \%$, three of which are Human Resources, Infrastructure and Technology Resources and Management, they are at an intermediate level in terms of meeting the elements for achieving competitiveness, however, it is inferred that there are opportunities for improvement to raise these levels in the medium, because although it is known that work is being done correctly, it is important to identify why a higher level is not being achieved at these levels. This is not making it possible to increase overall competitiveness in the sector.
Finally, there is the third level of frequency, made up of the Processes and Environmental Management, where a level of competitiveness greater than $80 \%$ is reached, and in which it can be deduced that these are the aspects that strengthen the organizations within the sectorbeing among the highest percentages achieved, it is established that this is where the best way is being worked so that organizations can stay competitive, however, it is considered essential to follow up on these elements that are being developed in a prominent manner and to develop programs that can further strengthen them.

After carrying out the analysis in a global way, and understanding the extent to which work is being done on each aspect, it can be noted that the economic, technological and cultural variables are strongly influencing so that the companies in the sector are not being competitive, as mentioned, within the context, economic changes are taking place both regionally and nationally, and this is impacting so that organizations are having difficulty staying financially stable, and as a result, they may also be lagging behind in the implementation of new technologies. And the lack of effective training programs for optimizing operations with existing infrastructure.

In addition to this, it is analyzed that the cultural aspect of the organization may be adversely influencing to achieve high levels of competitiveness, as this implies human behavior, and it is well known that human capital is the one that generates the results. It is achieved to detect that in organizations there is no established ideology in which a culture of quality is established, which must begin with a total knowledge of the context in which they are involved, adequate planning based on strategic objectives, participation, collaboration and communication at all hierarchical levels, as well as the promotion of creativity and innovation, since it is essential that more and more value is added to the service offered. It is important to note that a plan for continuous improvement is not clearly and concretely established within organizations. Where measurement and generation of indicators for results are the tool to understand how work is being done and the specific points where it can be improved, through global strategies and the inclusion of effective response actions to developments in the environment. 
With regard to political, social and environmental factors, it can be emphasized that companies are not being affected, since in these respects organizations are in a favorable position, these are the variables where the most emphasis is placed on the time of service delivery, as a general rule, these organizations will have to comply with legal issues to strengthen them, as this represents the final impact and rationale of the companies from the legal point of view. And they are therefore being managed in a stable manner by monitoring movements concerning new government positions to reduce the negative impact that might lead to the provision of these services. It is therefore a plane where organizations must remain strict and strengthened in the face of possible changes that may arise in a future scenario, as stability in the region in which they are located depends on this.

\section{Conclusions}

Under the service delivery company scheme, many organizations fail to transcend and remain competitively to achieve ideal levels of productivity. The results of this study clearly indicate that the context variables (economic, technological and cultural) significantly affect the development of the competitiveness of the sector, as economic changes are taking place, the direct impact is manifested in the organizations, and present a financial imbalance, which reduces the opportunities for growth, improvement and implementation of new technologies, as well as the lack of effective training programs for the optimization of infrastructure operations currently in place. If the analysis of each of the variables in the context is based, a scheme or model that shows comprehensive improvement strategies can be generated and proposed, so that these will lead the companies providing services to evolve as highly professional entities, with the opportunity to transcend not only at the regional level, but also at the national and international level.

\section{References}

Bonales Valencia, J., Zamora Torres, A.I. y Ortiz Paniagua C.F., (2015). Variables e Índices de Competititividad de las Empresas Exportadoras, utilizando el PLS, CIMEXUS, Vol. X, No. 2.
Cervilla, Maria Antonia. (Enero, 2001). La competitividad del sector conexo a la industria petrolera desde una perspectiva de desarrollo de clusters. Espacios. Vol. 22.

De la Vega, Ángel. (2003). La industria petrolera mexicana en el marco de las tendencias globales del cambio institucional, organizacional y tecnológico. Coloquio Internacional: Energía, Reformas Institucionales y Desarrollo en América Latina", UNAM/Université Pierre Mendès France de Grenoble, Ciudad Universitaria, 5-7 de noviembre 2003. Publicado en revista OGEL (Oil, Gas, Energy Law), Special Edition, Vol. 2, pp. 99-120, 2004.

Hernández Rodríguez, D. F. (2021). La dualidad del petróleo en Colombia: positivo futuro económico basado en su dependencia (Master's thesis, Maestría en Negocios InternacionalesVirtual).

Martínez Trejo, Isaías, Reforma Energética y estrategias para la competitividad del sector petrolero, Revista Iberoamericana de Producción Académica y Gestión Educativa, 2016

Martínez, Elizabeth. (2015). Crean organismo para hacer empresas tabasqueñas más competitivas Ante retos de Reforma Energética. 15 de noviembre de 2019, de PetroQuimex. https://petroquimex.com/PDF/MayJun16/Institut o_Tabasqueno.pdf

Mejía Lugo, Eugenia Marisol, La Competitividad de la Industria Petroquímica Mexicana, Tiempo Económico, Num. 12, vol IV, 2009

Shields, David. (2003). Pemex. Un futuro incierto. Editorial Planeta Mexicana, México, p. 168

Walde, Thomas. (2002). Implicaciones legales y políticas de una relación de dos tratados internacionales en recursos energéticos naturales: la OPEP y el TCE. CEPMLP/Dundee, p. 120 